\title{
EFFECT OF FLOOD AND DRIP IRRIGATION SYSTEMS ON GROWTH AND PRODUCTIVITY OF PICUAL AND ARBEQUINA OLIVE CVS. GROWN IN NEW RECLAIMED LANDS
}

\author{
Morsi, M. E. \\ Dept. of Horticulture, Fac. of Agric., Fayoum Univ., Egypt \\ ABSTRACT \\ Water use (WU), water use efficiency (WUE), growth, \\ productivity of Picual and Arbequina olive cultivars were studied \\ under two irrigation systems (flood and drip) during 2007and \\ 2008 seasons. \\ Results showed that, seasonal water use of olive trees grown \\ under flood and drip irrigation was 704.04 and 446.95 \\ $\mathrm{mm} /$ feddan/year, respectively (average of the two seasons). Olive \\ trees subjected to drip irrigation produced the highest yield/tree \\ $16.6 \mathrm{Kg}$ (average of the two seasons). Yield decreased by about \\ $23.67 \%$ when trees were exposed to flood irrigation system. Yield \\ efficiency and water use efficiency of olive tress had the same \\ trend. The maximum values, in this respect, were obtained by olive \\ trees grown under drip irrigation followed in a descending order by \\ flood irrigation, respectively. \\ On the contrary, olive trees grown under flood irrigation \\ system gave higher values of vegetative growth parameters and \\ percent of fruit dry weight. However, it gave less fruit yield as well \\ as percent of oil in flesh dry weight. Olive trees grown under drip \\ irrigation system gave the highest value of oil\% per flesh dry \\ weight (43.99\% average of the two seasons). Meanwhile, this \\ percent decreased by about $8.54 \%$ when trees were irrigated by \\ flood irrigation. \\ Moreover, from the obtained data, it is clear that Picual cv. had \\ that bigger tree canopy, fruit yield, fruit weight, fruit dry matter \\ and fruit oil content more than Arbequina cv. \\ Consequently, it could be recommended cultivate trees of \\ Picual cv. in the new reclaimed land as it was more suitable than \\ Arbequina cv.
}

Key words: Olive trees, Irrigation system, Water use, Water use efficiency, Yield efficiency, Growth parameters, Yield and fruit quality.

\section{INTRODUCTION}

Due to the increasing limitation of water availability for irrigation in large areas of the world, there is an increase risk of loosing irrigated land. However, for mature fruit trees, reducing applied water to a certain limit could improve water use efficiency (Glenn, 2000). Applying water to fruit tree crops is a widely used practice but efficient water use has become important only in recent years due to the rapid depletion of available water resources in many areas of the world (Kang et al., 2002).

Olive cultivation has an important role in agricultural production. Since, it increases the land value especially where soil is unsuitable for other fruit crops due to its capability to grow under several conditions (Abd-El Samad, 1995).

Fayoum J. Agric. Res. \& Dev., Vol.23, No.1, January, 2009 
In many olive-growing situations, water for irrigation is not always available in sufficient volumes to completely satisfy crop requirements. Moreover, there are ever-increasing cases in which there are regulations restricting the use of public water (Pastor-Muaz, 2001). The above situation has given rise to trials to study some irrigation strategies aiming to ascertain the possibility of irrigating the olive with deficit volumes during some specific phenological phases, and has generated methods based on recharging the land's water endowment during periods of water availability.

Improving irrigation efficiency also means equipping producers with suitable irrigation methods. The most efficient water distribution methods are the localized ones, of which the drip irrigation method permits the greatest saving in the irrigation volume (D'Andria et al., 2004).

From the view of water saving of olive trees, the drip irrigation system can be used to insure good distribution of soil moisture in the root zone depth without rising the soil moisture which cause, a low production of olive tress (Hussein, 2008).

Abd El-Samad, (1995) concluded that the highest vegetative growth, yield, fruit quality and water use efficiency of olive trees were greatest when irrigation was applied at $60 \%$ available water (4770.30 $\mathrm{m}^{3} /$ f.) followed in a decreasing order by the medium treatment $40 \%$ A.W $\left(4193.06 \mathrm{~m}^{3} / \mathrm{f}\right.$.) and then the dry treatment $20 \%$ A.W $\left(3805.92 \mathrm{~m}^{3} / \mathrm{f}\right.$.). Therefore, he recommended that irrigation at $60 \%$ available water was promising for the best growth and yield of olive trees. In addition crop coefficient $(\mathrm{Kc})$ of olive trees was 0.69 for high available soil water and 0.55 for trees under water stress, using this $\mathrm{Kc}$ values could be recommended for determining water use for olive trees in other areas.

\section{MATERIALS AND METHODS.}

This trial was carried out during two successive seasons of 2007 and 2008 on two olive cvs. namely Picual and Arbequina grown in Kom Osheem farm at Fayoum Governorate, Egypt, established by the EgyptianSpanish project; belonging to Ministry of Agriculture and Land Reclamation to study the effect of flood and drip irrigation system on water use, growth and productivity of olive trees. The trees were about 7 years old, planted at $4 \times 4 \mathrm{~m}$ apart and grown on sandy loam soil (new reclaimed lands). Physical and chemical characteristics of the soil are shown in tables $(1,2)$.

The Experiment was designed as factorial experiment in complete randomized blocks and consists of two treatments: flood and drip irrigation. Each treatment replicated three times on five trees/replicate and the central three trees were used for experimental measurements.

Under flood irrigation system, olive trees were irrigated at $60 \%$ available soil water. Soil samples were collected from different locations at $0-60 \mathrm{~cm}$ from the soil surface before and after irrigation and water use was measured by soil moisture measurements according to Issraelson and Hansen (1962). Water use was computed for all irrigations from $15^{\text {th }}$ Feb. till the end of November.

Under drip irrigation system, olive trees were irrigated at $100 \%$ of classe A pan $\left(\mathrm{ET}_{\text {pan }}\right)$ which placed in the experimental station. Irrigation

Fayoum J. Agric. Res. \& Dev., Vol.23, No.1, January, 2009 
treatments were applied twice a week from $15^{\text {th }}$ Feb. till the end of April and, three times a week from May till Nov. of each season. Irrigation was achieved by installing a lateral line equipped with shut off valves at each treatment/plot.

Tree height and width were measured in Oct. in each season to calculate the canopy volume according to Turrell (1946) using the following formula: Canopy volume $=0.5236 \times \mathrm{HD}^{2}$

Where $\mathrm{H}=$ tree height and $\mathrm{D}=$ tree width.

In $15^{\text {th }}$ Oct. of each season, 5 secondary branches were chosen randomly on each side of the tree to determine shoot length $(\mathrm{cm})$ and leaf area $\left(\mathrm{cm}^{2}\right)$ using digital planimeter (planix 7).

The fruit yield as $\mathrm{kg} /$ tree was estimated and water use efficiency (WUE) as " $\mathrm{Kg}$ fruit $/ \mathrm{m}^{3}$ of irrigation water" and yield efficiency "kg fruit $/ \mathrm{m}^{3}$ of canopy volume" were calculated. Sample of 20 mature fruits were randomly chosen/tree to determine average fruit weight. Oil content was determined by extracting the oil from the dried flesh samples according to (A.O.A.C., 1975).

Data were statistically analyzed according to (Snedecor and Cochran, 1980) and differences between means were tested using L.S.D at $5 \%$ level.

Table (1): Physical characteristics of the experiments soil.

\begin{tabular}{|c|c|c|c|c|c|c|c|c|c|}
\hline \multirow[b]{2}{*}{ Depth } & \multicolumn{4}{|c|}{ Particle size distribution } & \multirow[b]{2}{*}{ Texture } & \multirow{2}{*}{$\begin{array}{c}\text { Bulk } \\
\text { density }\end{array}$} & \multicolumn{3}{|c|}{ Soil moisture constant } \\
\hline & $\begin{array}{l}\text { Coarse } \\
\text { sand\% }\end{array}$ & $\begin{array}{c}\text { Fine } \\
\text { sand \% }\end{array}$ & Silt \% & $\begin{array}{c}\text { Clay } \\
\%\end{array}$ & & & F. C. & W.P. & A.W. \\
\hline 0-30 & 51.0 & 29.8 & 10.7 & 8.5 & $\begin{array}{l}\text { Sandy } \\
\text { loam }\end{array}$ & 1.42 & 17. 99 & 7.35 & 10.64 \\
\hline $30-60$ & 50.5 & 28.4 & 11.9 & 9.2 & $\begin{array}{c}\text { Sandy } \\
\text { loam }\end{array}$ & 1.48 & 13.19 & 6.30 & 6.89 \\
\hline
\end{tabular}

Table (2): Chemical characteristics of the experiments soil.

\begin{tabular}{|c|c|c|c|c|c|c|c|c|c|}
\hline \multirow[t]{2}{*}{ Depth } & \multicolumn{4}{|c|}{ Soluble cations $(\mathrm{meq} / \mathrm{L})$} & \multirow[t]{2}{*}{ pH } & \multirow{2}{*}{$\begin{array}{c}\text { Ece } \\
\mathrm{dS} / \mathrm{m}\end{array}$} & \multicolumn{3}{|c|}{ Soluble anions (meq/l) } \\
\hline & $\mathrm{Ca}^{++}$ & $\mathrm{Mg}^{++}$ & $\mathrm{Na}^{++}$ & $\mathbf{K}^{++}$ & & & $\mathrm{Cl}^{-}$ & $\mathrm{HCO}_{3}^{-}$ & $\mathrm{So}_{4}^{--}$ \\
\hline $0-30$ & 14.60 & 13.21 & 13.30 & 1.51 & 7.60 & 4.18 & 7.11 & 2.71 & 32.80 \\
\hline $30-60$ & 8.04 & 7.57 & 4.15 & 0.73 & 7.65 & 2.01 & 3.48 & 2.96 & 14.05 \\
\hline
\end{tabular}

RESULTS AND DISCUSSION.

It is clear form the data in Table (3) that the monthly water use, $(\mathrm{mm} / \mathrm{month})$ was increased gradually from Fep. up to June, then decreased up to Nov. therefore, the maximum values were obtained in June; this increase was due to the development of shoot growth, leaf area and evaporative demand. Meanwhile, the lowest values were detected during, October, November and February, respectively. In addition, seasonal water use of olive trees grown under flood irrigation was 678.64 $\mathrm{mm} /$ feddan/year in the first season and $729.44 \mathrm{~mm} /$ feddan/year in the second season. Meanwhile, the values of seasonal water use under drip irrigation system were 446.87 and $447.03 \mathrm{~mm} /$ feddan/year in the two studied seasons, respectively.

The present results are in agreement with that obtained by Michelakis and Vougloucalou (1988) and Chartzoulakis et al.,(1992) who reported that consumptive water use for olive trees differ by different

Fayoum J. Agric. Res. \& Deb!, ŁVol.23, No.1, January, 2009 
irrigation system and application date. Schakshouk and Allam (1994) noticed that monthly ETa for olive trees varied from month to another.

Table (3): Monthly water use (mm/month) of Picual and Arabequina olive tree cultivars grown under flood and drip irrigation systems during 2007 and 2008.

\begin{tabular}{|c|c|c|c|c|}
\hline \multirow{2}{*}{ Month } & \multicolumn{2}{|c|}{ Irrigation system } & \multicolumn{2}{c|}{ Irrigation system } \\
\cline { 2 - 5 } & \multicolumn{2}{|c|}{ Flood } & Drip & \multicolumn{2}{c|}{ Flood } & Drip \\
\cline { 2 - 5 } & \multicolumn{2}{|c|}{$\mathbf{2 0 0 7}$} & -- & -- \\
\hline Jan. & -- & -- & -- & 5.02 \\
\hline Feb. & 15.35 & 6.25 & 18.18 & 22.64 \\
\hline Mar. & 77.42 & 15.82 & 75.07 & 39.71 \\
\hline Apr. & 85.29 & 35.15 & 89.96 & 71.49 \\
\hline May & 99.50 & 65.62 & 100.73 & 64.87 \\
\hline Jun. & 104.00 & 67.69 & 109.28 & 62.43 \\
\hline Jul. & 93.60 & 65.22 & 88.13 & 69.45 \\
\hline Aug. & 83.76 & 66.78 & 81.28 & 50.23 \\
\hline Sep. & 71.73 & 55.13 & 74.77 & 37.52 \\
\hline Oct. & 63.34 & 41.62 & 52.97 & 23.67 \\
\hline Nov. & 4512 & 27.59 & 39.07 & -- \\
\hline Dec. & -- & -- & -- & 447.03 \\
\hline Total & 678.64 & 446.87 & 729.44 & \\
\hline
\end{tabular}

Growth parameters (Table, 4) of the two studied olive cvs. differ significantly by irrigation system. The highest values of canopy volume $\left(\mathrm{m}^{3}\right)$, and leaf area $\left(\mathrm{cm}^{2}\right)$ were detected by trees under flood irrigation, while the lowest significant values were obtained when trees were grown under drip irrigation. In addition, trees of Picual cv. showed the largest tree canopy as well as leaf area while trees of Arbequina cv. showed the smallest ones in the two studied seasons.

The increment of the growth parameters of olive trees grown under flood irrigation system may be due to the fact that flood system increased water and nutrients uptake which led to give the largest tree size. Vegetative growth of fruit trees is particularly sensitive to water deficit and there is a close relationship between moisture and organ enlargement (Syversten, 1985) on fruit trees; Abd El-Samad, (1995) on olive trees, and Abd El-Samad, (2005) on guava trees.

Table (4): Effect of drip and flood irrigation systems on tree canopy volume $\left(\mathrm{m}^{3}\right)$ and leaf area $\left(\mathrm{cm}^{2}\right)$ of Picual and Arbequina olive cvs.

\begin{tabular}{|c|c|c|c|c|c|c|}
\hline \multirow{3}{*}{ Cultivar } & Drip & Flood & Mean & Drip & Flood & Mean \\
\hline & \multicolumn{3}{|c|}{2007} & \multicolumn{3}{|c|}{2008} \\
\hline & \multicolumn{6}{|c|}{ Canopy volume $\left(\mathrm{m}^{3}\right)$} \\
\hline Picual & 4.39 & 5.35 & 4.87 & 5.09 & 6.07 & 5.58 \\
\hline Arbequina & 2.29 & 2.41 & 2.35 & 2.52 & 2.68 & 2.60 \\
\hline Mean & 3.34 & 3.88 & & 3.81 & 4.37 & \\
\hline \multirow[t]{2}{*}{ LSD at 5\% } & \multicolumn{3}{|c|}{$\begin{array}{l}\text { cv. }=0.47 \\
\text { cv. } \times \text { Irrg. }=0.52\end{array}$} & \multicolumn{3}{|c|}{$\begin{array}{l}\text { cv. }=0.38 \\
\text { cv. } \times \text { Irrg. }=0.25\end{array}$} \\
\hline & \multicolumn{6}{|c|}{ Leaf area $\left(\mathrm{cm}^{2}\right)$} \\
\hline Picual & 5.19 & 5.56 & 5.38 & 5.15 & 4.59 & 4.87 \\
\hline Arbequina & 3.73 & 3.77 & 3.75 & 3.75 & 3.91 & 3.83 \\
\hline Mean & 4.46 & 4.66 & & 4.45 & 4.25 & \\
\hline LSD at $5 \%$ & $\begin{array}{c}\text { cv. }=0 \\
\text { cv. } \times \text { Irrg }\end{array}$ & &.$=0.15$ & $\begin{array}{l}\text { cv. }=0.1 \\
\text { cv. } \times \text { Irr }\end{array}$ & $.17^{\text {Irrg }}$ & \\
\hline
\end{tabular}

Fayoum J. Agric. Res. \& Dev., Vol.23, No.1, January, 2009 
Pertaining data presented in (Table 5) obviously showed that yield per tree was affected significantly by irrigation system in the first and second seasons and by cultivars in the first season only. Olive trees subjected to drip irrigation produced the highest yield/tree $16.6 \mathrm{Kg}$ (average of the two seasons). In addition, yield decreased by about $23.67 \%$ when trees were exposed to flood irrigation system. Yield of Picual tree was $13.81 \mathrm{~kg}$ and $15.69 \mathrm{~kg}$, meanwhile it was $13.46 \mathrm{~kg}$ and $15.58 \mathrm{~kg}$ for Arbequina cv. in the two studied seasons, respectively.

These results are in agreement with Hussein (2008) who found that drip irrigation system can be used to insure good distribution of soil moisture in the root zone depth without rising the soil moisture which cause a low production of olive tress.

Fruit weight (Table, 5) was affected significantly by irrigation system and cultivars. Picual olive trees produced the heaviest fruit weight compared by Arbequina trees which gave the smallest fruit weight. Fruit weight was $3.68 \mathrm{~g}$ and $3.22 \mathrm{~g}$ for trees grown under flood and drip irrigation system, respectively (average of the two seasons).

Table (5) Effect of drip and flood irrigation systems on yield (kg/tree) and fruit weight (g) of Picual and Arbequina olive cvs.

\begin{tabular}{|c|c|c|c|c|c|c|}
\hline \multirow{3}{*}{ Cultivar } & Drip & Flood & Mean & Drip & Flood & Mean \\
\hline & \multicolumn{3}{|c|}{2007} & \multicolumn{3}{|c|}{2008} \\
\hline & \multicolumn{6}{|c|}{ Yield (kg/ tree) } \\
\hline Picual & 15.17 & 12.45 & 13.81 & 16.67 & 14.72 & 15.69 \\
\hline Arbequina & 16.33 & 10.59 & 13.46 & 18.24 & 12.93 & 15.58 \\
\hline Mean & 15.75 & 11.52 & & 17.45 & 13.83 & \\
\hline \multirow[t]{2}{*}{ LSD at $5 \%$} & \multicolumn{3}{|c|}{$\begin{array}{ll}\text { cv. }=0.20 & \text { Ir } \\
\text { cv. } \times \text { Irrg. }=0.71 & \end{array}$} & \multicolumn{3}{|c|}{$\begin{array}{l}\text { cv. = n.s. } \\
\text { cv. } \times \text { Irrg. }=1.64\end{array}$} \\
\hline & \multicolumn{6}{|c|}{ Fruit weight (gm) } \\
\hline Picual & 5.74 & 5.89 & 5.82 & 5.40 & 5.56 & 5.48 \\
\hline Arbequina & 1.11 & 1.71 & 1.41 & 2.08 & 1.55 & 1.82 \\
\hline Mean & 3.43 & 3.80 & & 3.01 & 3.56 & \\
\hline LSD at $5 \%$ & $\begin{array}{l}\mathrm{cv} .=0.7 \\
\mathrm{cv} . \times \text { Irrg }\end{array}$ & .19 & $=0.14$ & $\begin{array}{l}\mathrm{cv} . \\
\mathrm{cv} . \times \operatorname{Irr}\end{array}$ & & $=0.11$ \\
\hline
\end{tabular}

Table (6) Effect of drip and flood irrigation systems on water use efficiency and yield efficiency of Picual and Arbequina olive tree cvs.

\begin{tabular}{|c|c|c|c|c|c|c|}
\hline \multirow{3}{*}{ Cultivar } & Drip & Flood & Mean & Drip & Flood & Mean \\
\hline & \multicolumn{3}{|c|}{2007} & \multicolumn{3}{|c|}{2008} \\
\hline & \multicolumn{6}{|c|}{ Water use efficiency (Kg fruit / $/ \mathbf{m}^{3}$ of irrigation water) } \\
\hline Picual & 2.02 & 1.09 & 1.56 & 2.22 & 1.20 & 1.71 \\
\hline Arbequina & 2.18 & 0.93 & 1.55 & 2.43 & 1.05 & 1.74 \\
\hline Mean & 2.10 & 1.01 & & 2.33 & 1.13 & \\
\hline \multirow[t]{2}{*}{ LSD at $5 \%$} & \multicolumn{3}{|c|}{$\begin{array}{ll}\text { cv. }=\text { n.s. } & \text { Irrg. }=0.47 \\
\text { cv. } \times \text { Irrg. }=0.58 & \\
\end{array}$} & \multicolumn{3}{|c|}{$\begin{array}{ll}\text { cv. }=\text { n.s. } & \text { Irrg. }=0.76 \\
\text { cv. } \times \text { Irrg. }=0.94 & \end{array}$} \\
\hline & \multicolumn{6}{|c|}{ Yield efficiency (kg fruit/m $/ \mathrm{m}^{3}$ of canopy volume) } \\
\hline Picual & 3.48 & 2.33 & 2.91 & 3.28 & 2.43 & 2.86 \\
\hline Arbequina & 7.13 & 4.39 & 5.76 & 7.24 & 4.82 & 6.03 \\
\hline Mean & 5.31 & 3.36 & & 5.26 & 3.63 & \\
\hline LSD at $5 \%$ & \multicolumn{3}{|c|}{$\begin{array}{ll}\mathrm{cv} .=0.79 & \text { Irrg. }=1.14 \\
\mathrm{cv} . \times \text { Irrg. }=1.19 & \end{array}$} & \multicolumn{3}{|c|}{$\begin{array}{ll}\text { cv. }=0.58 & \text { Irrg. }=1.07 \\
\text { cv. } \times \text { Irrg.= } 1.44 & \\
\end{array}$} \\
\hline
\end{tabular}

Fayoum J. Agric. Res. \& DebУ, YVol.23, No.1, January, 2009 
Regarding yield efficiency, data presented in Table (6) revealed that yield efficiency and water use efficiency of olive tress were affected significantly by irrigation system and their interaction. The maximum values in this respect were obtained by olive trees grown under drip irrigation followed in a descending order by trees irrigated by flood irrigation, respectively. This trend was true in the two studied seasons. Also, values of yield efficiency were 5.76 and 6.03 for trees of Arbequina cv., and were 2.92 and 2.86 for trees of Picual cv. in the first and second season, respectively.

Table (7) Effect of drip and flood irrigation systems on fruit dry weight \% and oil \% of flesh dry weight of Piucal and Arbequina olive cvs.

\begin{tabular}{|c|c|c|c|c|c|c|}
\hline \multirow{3}{*}{ Cultivar } & Drip & Flood & Mean & Drip & Flood & Mean \\
\hline & \multicolumn{3}{|c|}{2007} & \multicolumn{3}{|c|}{2008} \\
\hline & \multicolumn{6}{|c|}{ Fruit dry weight \% } \\
\hline Picual & 61.94 & 64.72 & 63.33 & 61.24 & 63.78 & 62.51 \\
\hline Arbequina & 56.24 & 61.17 & 58.70 & 56.50 & 58.8 & 57.65 \\
\hline Mean & 59.09 & 62.94 & & 58.87 & 61.29 & \\
\hline \multirow[t]{2}{*}{ LSD at $5 \%$} & \multicolumn{3}{|c|}{$\begin{array}{ll}\text { cv. }=1.43 & \text { Irrg. }=0.63 \\
\text { cv. } \times \text { Irrg. }=0.89 & \end{array}$} & \multicolumn{3}{|c|}{$\begin{array}{ll}\text { cv. }=0.73 & \text { Irrg. }=0.77 \\
\text { cv. } \times \text { Irrg.= } 0.92 & \end{array}$} \\
\hline & \multicolumn{6}{|c|}{ Oil \% per flesh dry weight } \\
\hline Picu & 42.60 & 40.36 & 41.48 & 46.76 & 41.35 & 44.05 \\
\hline Arbequina & 44.27 & 36.93 & 40.60 & 42.33 & 43.50 & 42.91 \\
\hline Mean & 43.43 & 38.65 & & 44.54 & 42.42 & \\
\hline LSD at $5 \%$ & \multicolumn{3}{|c|}{$\begin{array}{l}\text { cv. }=\text { n.s. } \\
\text { cv. } \times \text { Irrg. }=0.29\end{array}$} & \multicolumn{3}{|c|}{$\begin{array}{ll}\text { cv. }=\text { n.s. } & \text { Irrg. }=0.54 \\
\text { cv. } \times \text { Irrg. }=0.76 & \end{array}$} \\
\hline
\end{tabular}

In addition, Water use efficiency did not affect significantly by cultivars in the two studied seasons.

The increment of the values of yield efficiency and water use efficiency for olive trees grown under drip irrigation system may be due to the saving of water use. On the contrary, flood system increases water and nutrients uptake and consequently, consumes higher values of irrigation water which gives larger tree size with lower fruit yield. Previous reports by (Girona et al., 1993; Glenn, 2000 and Parsons and Wheaton, 2000) have indicated that deficit irrigation water increased water use efficiency.

Data of fruit dry weight percent (Table7) indicated that trees of Picual gave the highest percent of fruit dry weight (62.97 average of the two seasons) and that was increased by about $8.25 \%$ than trees of Arbequina cultivar. In addition, percent of fruit dry weight was affected significantly by irrigation system and cultivars. Olive trees irrigated by flood irrigation produced the highest percent in this respect followed in a descending order by those grown under drip irrigation. The increase of the fruit dry weight percent of trees grown under flood irrigation may be due to the increment of total leaf area and photosynthesis rate during the entire growing period. This leads to an overall positive effect on the total production of the dry matter (Michelakis, 1990; Proietti and Antognzzi 1996).

It is obvious clear from the data present in (Table, 7) that oil percent had the opposite trend of fruit dry weight percent. Therefore, olive trees grown under drip irrigation system gave the highest significant value of

Fayoum J. Agric. Res. \& Dev., Vol.23, No.1, January, 2009 
EFFECT OF FLOOD AND DRIP IRRIGATION SYSTEMS ON .. 178

oil\% per flesh dry weight (43.99\% average of the two seasons). Meanwhile, this percent decreased by about $8.54 \%$ when trees were irrigated by flood irrigation. The values of oil percent of Picual and Arbequina were 41.48 and $40.60 \%$ in the first season, and 44.05 and $42.91 \%$ in the second season, respectively.

The present results indicated that trees of Picual trees had the highest values of vegetative growth parameters, yield and fruit quality. Meanwhile, trees of Arbequina gave the highest values of yield efficiency. In addition, olive trees irrigated by drip irrigation system were more promising than that grown under flood irrigation. Consequently, it could be conclud that trees of picual cv. are more suitable to cultivate in new reclaimed lands than Arbequina trees.

\section{REFERENCES}

Abd El-Samad, G.A. (1995): Effect of irrigation regimes on growth, yield and water use of olive trees. Ph.D. Thesis, Fac.of Agric., Fayoum, Cairo Univ., Egypt.

Abd El-Samad, G.A. (2005): Water use, growth and productivity of some new guava strains as affected by different irrigation regimes. Egypt. J. Hort. 32: 41-56.

A.O.A.C. (1975): Association of Official Analytical Chemists, Official Methods of Analysis. $12^{\text {th }}$ ed., Washington, D.C., USA.

Chartzoullakis, K.; N. Michelakis and I. Tzompankis (1992): Effect of water amount and application date on yield and water utilization efficiency of "Koroneiki" olives under drip irrigation. Adv. Hort. Sci., 6(2): 82-84. (Hort. Abst., 63; 5587)

D' Andria R. G. Moreli; S. Terenziani; D. Calandrelli and D. Fragnito (2004): Effect of water regime on five pickling and double aptitude olive cultivars (Olea europaea,L.). J. of Hort. Scie \& biotechnology, 78 : 15-23.

Glenn, D.M. (2000): Physiological effects of incomplete root zone wetting on plant growth and there implications for irrigation management. HortScience, 35 :1041: 1042.

Girona, J.; M. Mata; D. A. Goldhamer; R. S. Johanson and T. M. Dejong (1993): Patterns of soil and trees water status and leaf functioning drying regulated deficit irrigation scheduling in peach. J. Amer. Soc. Hort. Sci. 118-580-586.

Hussein, A.H. (2008): Response of Manzanillo olive (Olea europaea, L.) cultivar to irrigation regime and potassium fertigation under Tabouk conditions, Saudi Arabia. Journal of Agronomy (7) 285-296.

Israelsen, O.W. and V.E. Hansen (1962): Irrigation Principles and Practices. Utaha state Univ., Utaha, 3 rd (ed). pp. 231- 265 and 279.

Kang, S.; Hu Xiaotao, G. Ian and J. Peter (2002): Soil water distribution, water use, and yield response to partial root zone drying under a shallow groundwater table in a pear orchard. Scientia Horticulturae 92: 277- 291.

Michelakis, N. (1990): Yield response of table and oil olive varieties to different water use levels under drip irrigation. Acta Horticulturae 286: 271 274.

Michelakis, N. and E. Vougioucalou (1988): Water use, root and top growth of olive trees for different methods of irrigation and level of soil water potential . Olea 19: 17-31.

Fayoum J. Agric. Res. \& Deby, ,Vol.23, No.1, January, 2009 
Parsons, L.R. and T.A. Wheaton (2000): Irrigation management and citrus tree response in a humid climate. HortScienc 35: 1043 -1045.

Pastor Munz-Cobo, M. (2001): Avances en la tecnologia de la programacion de rigos en situaciones de bajia disponibilitad de agua en el olivar de la provinica de jaen . Expoliva (c.f. Andria, 2004)

Proietti, P. and E. Antognzzi (1996): Effect of irrigation on fruit quality of table olive (Olea europaea, L) cultivar Ascolana tenera. New Zealand J. of Crop and Horticultural Science, 24: 175- 181.

Schakshouk, A.M. and M.A. Allam (1994): Supplemental irrigation in northern western coast zone. Egypt National Center of Agric., November, 1994.

Snedecor, G.W. and W.G. Cochran (1980): Statistical Methods.7th (ed) Iowa state, Univ. press, Iowa USA.

Syversten, J.P. (1985): Interaction of water stress in fruit trees. HortScience, 20:1039-1046.

Turrell, F.M. (1946): Tables of surfaces and volume of spheres and of prolate and oblate spheroids spheroidal coefficients Univ. Calif. Press, Barkely USA.

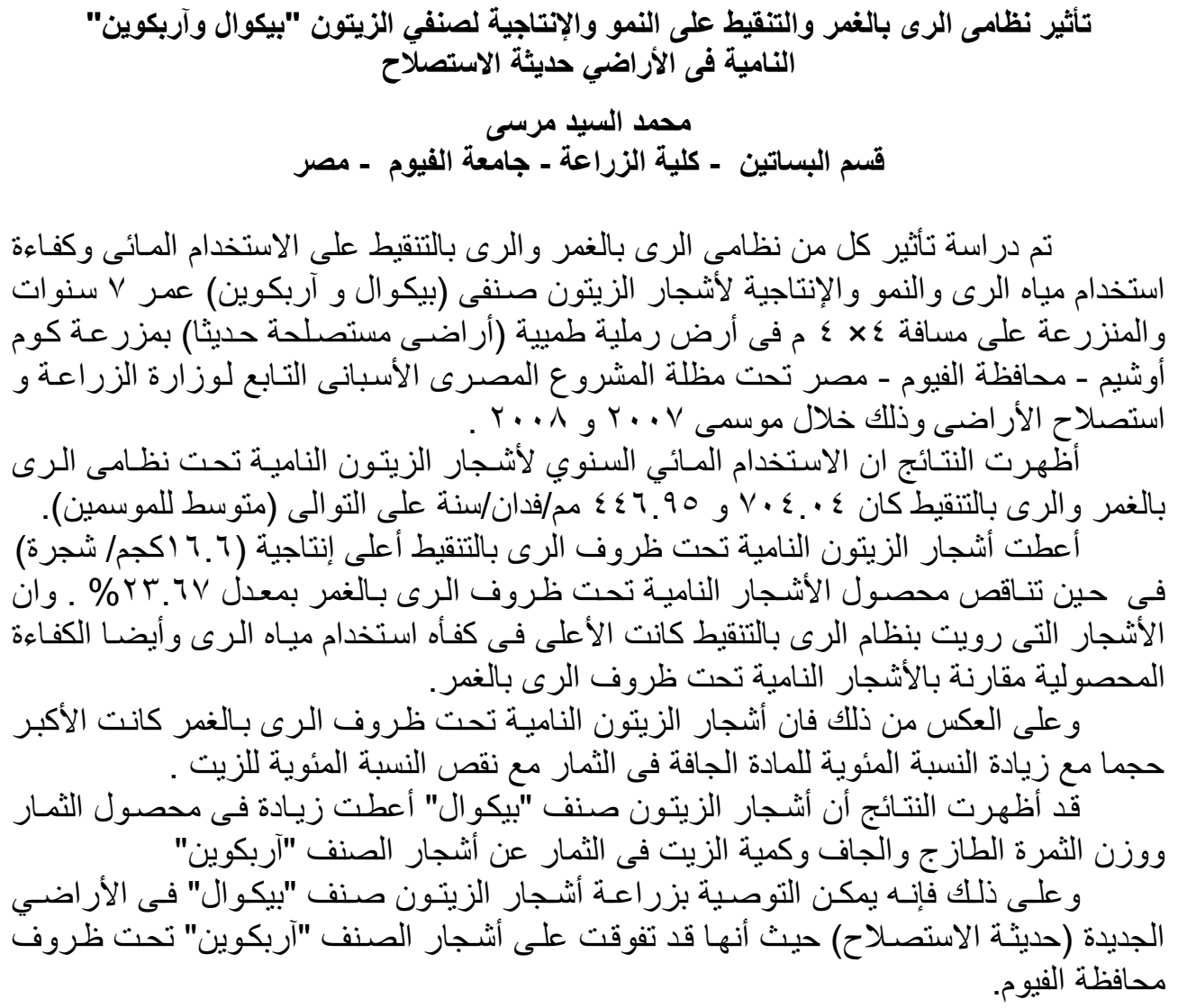

